\title{
LINCOLN AND DOUGLAS AND THE NAUGHTY NURSERY RHYME
}

\author{
BY WALTER E. BEZANSON
}

READERs of the Journal may recall Mr. Bezanson's article on the Crockett Almanac (June, 1949). He is a member of the departments of English and History at Rutgers and director of the major in American Civilization.

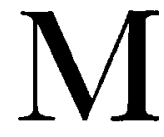

ILDLY obscene political pamphlets and moral tales for little folk, to be sure, are not quite the same thing, but apparently both were being published in Chicago ninety years ago. An amusing sample of one in the guise of the other has recently floated to the surface of the Rutgers University Library from among its ample holdings in Americana. It consists of five open sheets folded and stitched to make a small booklet which measures four and one quarter by three and three quarter inches. All the printed matter of this fugitive oddment (except title-page, preface, and the end word "MORAL") is in four-line verses under the cartoons.

This bit of wreckage from past politics is indeed a curious commentary on the election of 1860 - the climactic event of the most bitter and complex decade in all of American political life. For the historian of the American past it restores at a glance the story of the rough-and-tumble rancor that pursued the dynamic, unhappy career of the Little Giant, Stephen A. Douglas, unsuccessful candidate for President and advocate of "Popular Sovereignty" that crucial November. For the collector of Lincolniana it is an unusual and possibly rare item, since it contains, as will appear, what may well be the tiniest contemporary drawing of Lincoln on record. And for the student of American iconography here is the "donkey" as a Democratic party symbol antedating by ten years Nast's first use of it in a cartoon. ${ }^{1}$

Stephen Douglas has not prospered well in either formal history or folk memory. He had the good fortune to be allied in one fashion or another with each of the three great sections of American life, and the misfortune of losing majority support from each of them at the

${ }^{1}$ In the January 15, 1870 issue of Harper's Weekly, Nast published the cartoon "A Live Jackass Kicking a Dead Lion," which his biographer describes as "the earliest in which the donkey is used to typify Democratic sentiment." A. B. Paine, Thomas Nast: His Period and His Pictures (New York, I904), pp. I46-147. 
climax of his career. A Vermonter by birth, a Westerner by adoption, and a Southerner by alliance in two marriages, Douglas was peculiarly well situated to re-focus the split rays of sectional bias. And indeed he staked his position as a national figure on the platform of "Popular Sovereignty," the least sectional slogan of the decade. But the distinction between compromise and evasion is often a subtle one, and although Douglas proved to be the only candidate in 1860 whose popular votes came from all sections of the country, no state but Missouri gave him the majority which electoral votes are based on.

To understand the powerful position which Douglas occupied in mid-century politics and the reasons that he was crushed under such political vituperation as our little booklet provides, one needs biographical data. Fatherless at five weeks, restless as a boy in up-state Vermont, Douglas began to move West at seventeen. After picking up a smattering of law in northern New York he hit the trail in the mid-thirties, an adventurer in politics determined to fight his way up in the New West on the rough-and-tumble slogans of contemporary Jacksonism. Cleveland, Cincinnati, St. Louis, Jacksonville (Illinois) - and the son of a Vermont doctor was wearing Kentucky jeans, haranguing frontier crowds in favor of Old Hickory, and winning from them the supreme accolade of "Go it, little gamecock!" Somebody called him "a steam engine in britches" as he burst into Illinois state politics and blasted his way forward-a Judge of the State Supreme Court at twenty-eight! At thirty he was in the United States Congress, and at thirty-four in the national Senate, Chairman of the Committee on Territories ( I 847). "Steam-engine" indeed!

The Chairmanship of this Committee was a real hot-spot, for the crux of political dissension in the fifties was: Shall the territories (then nearly half of the present United States) be slave or free-shall the balance of power in national affairs go to the slave-holding states of the South or to the anti-slavery states of the North? It was a question that the American democracy found itself ultimately unable to cope with under its cherished standard of "a rule not of men but of law"; discussion, compromise and legislation gave way to bloody, internal war.

"Popular Sovereignty" was an idea as well as a slogan. Douglas picked it up from Lewis Cass, who in I 847 urged "leaving the people of any territory which may be hereafter acquired, the right to regu- 

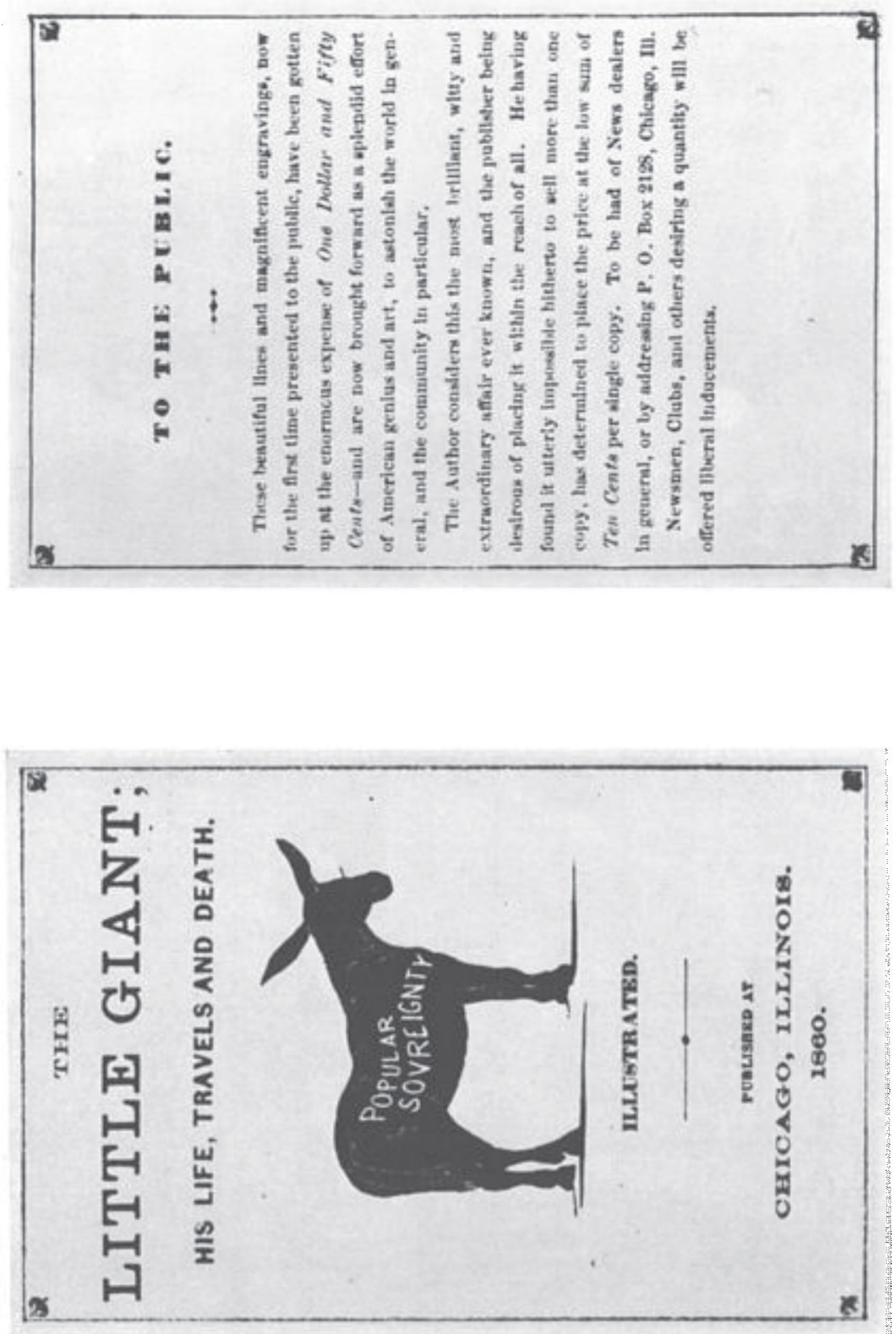
late it [slavery] themselves, under the general principles of the Constitution." '2 Douglas seems genuinely to have felt that this was advocacy of a politically sound American tradition: self-determination. To the question of whether the national government should permit slavery in the territories, or prevent it, Douglas replied it should do neither but content itself with insuring the procedural regularity whereby acquisitions became territories, and territories became states. On the level of practical politics it was a shrewd move to try to get this troublesome question out of the halls of Congress and into the local legislatures. But it didn't work that way.

It was in terms of "Popular Sovereignty" that Douglas successfully phrased that part of the famous Compromise of I 850 which allowed New Mexico and Utah to come into the Union free or slave, as they wished, when the time might come. But it was Douglas who framed and pushed through, with administration support, the disastrous folly of the Kansas-Nebraska Bill of 1854, which not only organized these new territories on the same principle of "Popular Sovereignty," but in so doing smashed the doctrines of the Missouri Compromise which had stood for thirty-four years. Bloody Kansas, John Brown's massacre, the drastic decision on Dred Scott, the disruption of the Democratic Party, and the formation of a purely sectional Northern party (Republican) - these events streamed out of the new chaos making war seem "irrepressible."

Nor did it help the case of Douglas, who in his lifetime made a million dollars on Chicago real estate, that his pushing through the bill for the new territories was at least related to his plans for a transcontinental railroad out of Chicago; such a railroad could go only through organized territory. Was the Little Giant, a demon of energy and ambition, proposing Realpolitik to save the Union without war, or was he a political opportunist who would dance whatever tune the piper might call? His enemies multiplied, calling him "Judas," pronouncing his name Stephen Arnold Douglas, burning his effigy, and contemptuously sneering about "Squatter Sovereignty." He was beginning to reap the whirlwind.

Yet energy and competence made him still seem, as he had seemed in 1852 and I 856 , the best Democratic hope for I 860 . Caught in a swirl of political repercussions, the Little Giant fought desperately

${ }^{2}$ Encyclopedia of the Social Sciences, XII, 240. 
to keep his place at the head of the party. He kept his place, but the party fell apart. ${ }^{3}$ At Charleston the Southern delegates walked out and nominated a candidate of their own, Breckinridge. A newly formed group, the Constitutional Union Party, nominated a second candidate, Bell. Douglas got the nomination of the Northern wing of the Democratic party when they met in Baltimore, but there he stood, candidate of a split party, facing the united forces of the Republicans headed by his old opponent from Illinois, Lincoln.

Douglas was on the way down, and seems to have realized it by mid-summer. For the first time in American history, a presidential candidate went out stumping for office, but it was too late. Lincoln went in in November, South Carolina went out in December, and gunpowder went up in April. Douglas, exhausted, died that June. Our mildly obscene pamphlet, then, was apparently published at Republican headquarters in Chicago, very probably during the summer or fall months of the campaign; for the illiterate bit of nonsense which is addressed "To The Public" makes it clear that copies were available for campaign use.

When the backwoods gods made Douglas and Lincoln, they pushed down on the head of one and pulled up on the bones of the other. From the waist up, Douglas was a husky man; broad shoulders carried his truly massive head, and his sonorous, resonant voice marked him a new Webster in an age when oratory was the favorite measure of a public man. Yet all the illusion fell off when he stood up. Douglas was exactly five feet four. His legs were too short. He was Daniel Webster-sawed off.

The two Illinois lawyers had sat together in the same state legislature as early as i 836 . And Lincoln had taken his six feet four to Congress in 1847 , the year that Douglas moved from Congress to Senate. Then in the summer of 1858 the two rivals campaigned through the dusty towns and hot cities of Illinois for the same office of State Senator; the little giant now came face-to-chest with the lanky man from Springfield in the seven historic debates that have been preserved so lovingly in the American myth. By frontier terms it was gamecock against half-horse-half-alligator, and though the gamecock won, the alligator plucked his feathers.

\footnotetext{
${ }^{3}$ Roy Nichols, The Disruption of American Democracy (New York, 1948), Chap. XV, and passim.
} 
Plucked his feathers forever, it is probably fair to say. The people have put it this way: it is known that when Douglas was courting the pretty girls of Springfield in the early I 840 o among them was Mary Todd; Mary Todd, the people of the region feel sure, refused the attentions of Douglas because she wanted to marry a President. ${ }^{4}$ It may well be that Stephen Douglas' greatest misfortune, historically, was not that he was beaten for President, but that he was beaten by Abraham Lincoln. Douglas was quite as inadequate as the other leaders of the fifties in preventing the war, but such modern charges as that he was "morally obtuse" may take their stress from his unlucky role of playing opposite the man who was to become for Americans the very embodiment of the moral law, compassionately interpreted. Few are the men or women who surrounded Lincoln, including his wife, his generals, his cabinet, his vice-president, who have not suffered vilification. Perhaps there can be only one savior.

But to return to the pamphlet of 1860 . While the main contention of the rhymes is quite as clear as a small boy thumbing his nose, some of the political implications of the verse should be emphasized: I) the cock-sure manner of the ridiculous little man; 2) his catering to all parties, apparently including negroes; 3) the enemies he made by his love for popular sovereignty; 4) the device he used of "going to see his mother" back in New England, campaigning en route; 5) his coming a-cropper of the railsplitter in I 858 and after; and, certainly the unkindest cut of all, 6) his anticipated political "death" with Lincoln triumphant.

The last cartoon is particularly interesting. Here the western iconography is terse and real-a frontier image of prairie death beside the basket-like ribs of the donkey skeleton. Close by is the sign of Demon Rum, for Douglas had never been one to stint on board or bottle. There lies the Little Giant with the great head, prostrated in political death. Slain by whom? If one looks closely at the rising sun, he can see the figure (one eighth of an inch high) of a man. But it is clearly a lanky figure of a man, axe raised above a rail fence: long-legged Mr. Lincoln of Illinois, the Little-Giant killer.

\footnotetext{
${ }^{4}$ George F. Milton, The Eve of Conflict (Boston, 1934), p. 23. $62 \mathrm{I}$.

${ }^{5}$ Morison and Commager, Growth of the American Republic (New York, 1950), I,
} 